\title{
Cultural and Sociocultural Elements of Language Learning for the Turkish Learners of English in Two Different Universities
}

\section{Burak Tomak $^{1}$}

${ }^{1}$ Dr., Marmara University, Istanbul/Turkey

ORCID: 0000-0001-6678-431X

E-Mail

buraktomak@hotmail.com

Corresponding Author: Burak Tomak

January 2022

Volume: 19

Issue: 45

DOI: 10.26466//opusjsr.1062860

\section{Citation:}

Tomak, B. (2022). Cultural and Sociocultural elements of language learning for the Turkish learners of English in two different universities . OPUS- Journal of Society Research, 19(45), 116-128.

\begin{abstract}
Culture is one part of the language learning process and it has been defined and categorized by several scholars. With the advent of social constructivism in education, the sociocultural learning theory has come to the foreground. Therefore, these two important concepts have affected the language teaching pedagogy. Thus, this study aimed at determining the cultural and sociocultural elements that were focused in language classes in two different universities in Turkey. Hence, for the purpose of this study, five students from a state university in Istanbul and five students from another state university in Eskisehir were interviewed to find out whether these elements were covered in the language classes of the School of Foreign Languages in these two different university contexts. Additionally, some other contextual factors that affected these learners' sociocultural learning process were also questioned. The results showed that some aspects of culture were more stressed in language classes whereas some of them were neglected. Participants also stated that they benefitted a lot from the elements of sociocultural learning theory especially in terms of "scaffolding" as they cooperated with their peers whose level of language proficiency was higher than themselves to improve their language skills, especially writing and grammar.
\end{abstract}

Key Words: Culture, Sociocultural Learning, Scaffolding, Language Development, English Language Learning.

Öz

Kültür, dil öğrenme sürecinin bir parçasıdır ve bazı bilim insanları tarafından tanımlanmış ve kategorize edilmiştir. Eğitimde sosyal yapılandırmacılığın ortaya çıkmasıyla birlikte sosyokültürel öğrenme teorisi ön plana çımııştır. Bu nedenle, bu iki önemli kavram dil öğretimi pedagojisini etkilemiştir. Bu sebeple de bu çalışma Türkiye'deki iki farkh üniversitede dil derslerinde odaklanan kültürel ve sosyokültürel unsurları belirlemeyi amaçlamaktadır. Nitekim bu çalışmanın amacı doğrultusunda, İstanbul'daki bir devlet üniversitesinden beş öğrenci ve Eskişehir'deki başka bir devlet üniversitesinden beş öğrenci ile "görüşme" (mülakat) yoluyla bilgi toplanmış ve bu unsurların bu iki farklı üniversite bağlamındaki Yabancı Diller Yüksekokulu'nun dil derslerinde işlenip işlenmediğine bakılmıştır. Ek olarak, bu öğrencilerin sosyokültürel öğrenme sürecini etkileyen diğer bazı bağlamsal faktörler de sorgulanmıştır. Sonuç olarak, dil derslerinde kültürün bazı yönlerinin daha fazla vurgulanırken bazllarının ihmal edildiğini bulunmuştur. Katılımcılar ayrıca dil yeterlilikleri kendilerinden daha yüksek olan akranlarıyla özellikle yazma ve dilbilgisi becerilerini geliştirmek için iş birliği yaparak sosyokültürel öğrenme teorisinin unsurlarından özellikle "iskele" açısından çok faydalandıklarım belirttiler.

Anahtar Kelimeler: Kültür, Sosyokültürel Öğrenme, İskele, Dil Gelişimi, İngilizce Dil Öğrenimi. 


\section{Introduction}

Culture is an important part of language teaching process. It can be as "the system of shared beliefs, values, customs, behaviors, and artifacts that the members of society use to cope with their world and with one another and that are transmitted from generation to generation through learning" (Bates \& Plog, 1991, p.7). Thus, it can be concluded that every society has its own cultural aspects of thinking within the scope of their way of lives. Kramsch (1998) relates culture with "the membership in a discourse community that shares a common social space and history, and common imaginings" (p.10).

Cultural knowledge is significant for language learners as language and culture are inseparable from each other. Wright (1996) emphasizes the significance of culture in ELT pointing out the need "to raise awareness of the importance of culture in language education" (p.37). Nault (2006) concentrates on how the culture will be taught as it is obviously necessary for teachers to make culture part of their lesson plans. Byram (1997) confirms that "language and culture cannot be treated separately in the discussion of language teaching theory and practice" (p.52).

The important point here is to make "culture" more specific as it is such a broad term that it may include all parts of traditions and procedures applied within a certain community. There are different categorizations and components of culture that have been put forward by some researchers. Adaskou et al. (1990) proposed four components of culture in their article which are (i) the aesthetic sense (media, cinema, music and literature); (ii) the sociological sense (family, education, work and leisure, traditions); (iii) the semantic sense (conceptions and thought processes); (iv) the pragmatic (or sociolinguistic) sense ('appropriacy' in language use). The aesthetic sense is the culture with a capital " $\mathrm{C}$ ", reflecting media, cinema, music, literature, etc. The sociological sense of culture with a small " $c$ " refers to the structure and nature of family, home life, interpersonal relations, material conditions, work and leisure, customs and institutions. This component is the main focus of this study. The semantic sense is the conceptual system embodied in the language, covering many semantic areas such as food, clothes and institutions. The pragmatic sense means "the background knowledge, social skills, and paralinguistic skills that, in addition to mastery of the language code, that make possible successful communication".

Another categorization was made by Byrd et al. (2011):

1. Cultural products (tangible productsliterature, art, crafts and song, dance)

2. Cultural Practices (knowledge of what to do, when, and where)

3. Cultural Perspectives (ideas and attitudes)

These different components of culture and their effects on learning a foreign language have been investigated in this study considering the contextual factors.

\section{Literature Review}

There are different schools of thought in second language acquisition, all of which have been explained in the book of Brown (2007): Structural Linguistics and Behavioral Psychology, Generative linguistics and Cognitive Psychology, and Constructivism: A Multidisciplinary Approach, in which social constructivism has been defined as "social interaction and cooperative learning in constructing both cognitive and emotional images of reality" (p.12). Another scholar, Spivey (1997) exclaims that constructivist research most likely to focus on "individuals engaged in social practices, on a collaborative group, [or] on a global community" (p.24). Kaufman (2004) emphasizes the huge impacts of society and environment on the learning process by saying "children's thinking and meaning-making is socially constructed and emerges out of their social interactions with their environment" (p.304). Nunan (1992) elaborates on the issue by saying:

"I believe that success or failure in language learning is critically dependent on social, interpersonal and cultural factors, and that unless we develop methods for incorporating these factors into our research agenda, our knowledge of what makes learners tick will remain piecemeal and incomplete. Current research based on the so called "scientific" method alone are unlikely to 
provide us with anything like a complete picture of the acquisition process" (p.16).

He emphasizes the importance of social, cultural and interpersonal elements that play a crucial role in the language learning process. Therefore, these elements must be paid attention in language learning/teaching process. What is more, McLaughlin (1994) claims that today's students are significantly different from the ones that belong to previous generations; especially in terms of the cultural perspectives, languages, family circumstances, values, and mores that they bring to their classrooms. This means that learning cannot be separated from the social and contextual factors that directly affect the efficiency of the education.

\section{The Elements in Sociocultural Learning}

It is known that the key concepts related to social constructivism have been come up with by Vygotsky (1978; as cited in Brown, 2007). Thus, Vygotsky (1987) has come up with certain concepts that affect the second language teaching keeping the sociocultural theory in mind.

He emphasized the importance of "bilingual instruction" which means that the first language of the learners might be used in second language teaching because it will facilitate the process in a positive way. There are lots of studies that confirms the efficiency of the first language use in language classes because students will feel more comfortable when their L1 is also used in the instruction (Shweers,1999; Kim Ahn, 2010; Atkinson, 1987; Edstrom, 2006).

Another important point mentioned by Vygotsky (1997) is the "pragmatics" of the language. He thinks that without understanding the contextual factors that give the meaning to the conversation, a language learner with a perfect grammar and vocabulary knowledge will not be able to comprehend what is going around well. Canale and Swain (1980) mentioned four different characteristics of communicative competence which are grammatical competence that shows the importance of the structural rules of the language, sociolinguistic competence with which sociocultural context has gained some significance in language teaching, discourse competence which puts the importance of pragmatics into the foreground and the strategic competence

"Instruction based on learners' interest" is another point concentrated on by Vygotsky (1997). According to him, if the content of the learning appeals to the students, they will be more enthusiastic to learn and take part in the learning process. Genesee (1994) confirms that the content of the lessons does not need to be academic but it may include any topic of an interest and importance to learners.

"The role of the teachers" has also been specified under this theory and Vygotsky (1997) claims that teachers must play an active role in the dynamic nature of language teaching, which means that they have to act as the "director of the social environment" (p.339). In other words, teachers are responsible for making the necessary arrangements in the learning environment to make it suitable for the learners who will feel that there are perfect conditions which have been previously arranged to facilitate their learning. Thus, teachers must also guide their students' learning process out of their school time. They may assign some tasks for them to be completed to improve their language skills. These assignments might require social interaction between peers or other adults who can provide the learners with some benefits that they need to improve their language proficiency.

The interaction phase is an indispensable part of sociocultural learning theory. This interaction might take place among students who might directly contact with either their peers or with other adults out of their school context. This process might come up the term "zone of proximal development" which has been defined by Vygotsky (1978) as "the distance between the actual developmental level as determined by independent problem-solving and the level of potential problem-solving abilities as determined through problem solving under adult guidance or in cooperation with more capable peers" (p.86). This means that a more deficient learner will benefit from the knowledge of a more proficient peer or an adult who will facilitate the former's learning process. Cook (2008) articulates that "the 
gap between the learner's current state and their future knowledge is bridged by assistance from others; learning demands social interaction so that the learner can internalize knowledge out of external action" (p.229). In order for such a learning to take place, cooperation and collaboration among the students are needed by means of social interaction. Newman, Gleitman, and Cole (1989, cited in Lantolf \& Thorne, 2006) consider dialogic interaction and social mediation as the necessary elements for learning and development to occur. This ZPD (Zone of proximal development) concept has brought up another term "scaffolding", which has been defined by:

"the knowledgeable person (adult, teacher, or peer) helps the less knowledgeable (child, or student) to accomplish a task which he or she would not otherwise be able to do by himself or herself. It is also interpreted as anything a learner benefits from or consults with, which might be a dictionary, grammar books, the traditional classroom technique of Initiation, Response, and Follow up (IRF), or any corrective feedback offered by the teacher" (p.689).

It can be concluded from the quote above that scaffolding can be provided to the learners either by means of their peers and teachers or the materials that they use to improve their language proficiency.

These are the elements that have been incorporated in sociocultural learning theory. These elements have been explained briefly and their role in language learning in terms of the efficiency have long been questioned.

The aim of study

Though there have been some papers that explains the sociocultural learning theories in language teaching that focus on certain constructs of the theory and their effects on language learning (Fahim \& Haghani, 2012, Eun \& Lim, 2009; Nunan, 1992), there are very few studies carried out to observe the reflection of sociocultural learning theories in the real classrooms (Özfidan et al., 2014). In the latter study, the effect of three different factors (peer feedback, private speech, and self-efficacy) on sociocultural learning of the students have been observed in a class. However, this study was conducted to determine how both the cultural factors and some of the principal constructs of sociocultural learning theory by Vygotsky (1987) had an impact on language learning process of the students who took their preparation year in which they were exposed to intensive language learning program in two different cities of Turkey. As the context is one of the crucial factors that has an impact on every learning process, the effect of it on the sociocultural learning environments must be investigated. Thus, the researcher tried to determine the influence of the context on both cultural learning and sociocultural learning elements. The research questions of this study are:

- What are the cultural elements focused on during the language teaching in these two different university contexts?

- What are the elements that affect sociocultural learning of these students?

- How are the certain elements in sociocultural learning theory handled in two different learning contexts?

\section{Method}

\section{Research Design}

This is a case study which was defined by Hitchcock and Hughes (1995) as:

"Case studies are set in temporal, geographical, organizational, institutional and other contexts that enable boundaries to be drawn around the case; they can be defined with reference to characteristics defined by individuals and groups involved; and they can be defined by participants' roles and functions in the case" (p.319).

It can be understood that it is a context-bond study and the conclusions drawn from this research were based on the views of the participants in the context of the study. What is more, the effects of the variables determined and explained in the previous part of this paper were investigated as Cohen et al. (2007) elaborate that "case studies can establish cause and effect, indeed one of their strengths is that they observe effects in real contexts, recognizing that context is a powerful determinant of both causes and effects" (p.253). For this reason, two different university contexts were determined and five different 
students who were willing to participate in this were selected from each university and ten students in total were interviewed to collect data for the purpose of this study.

\section{Study Group}

As this is a contextual case study, two different student profiles were need to make a better comparison between the two contexts in which the data were collected. Thus, 5 students were chosen at their own will from a state university in Eskisehir in the Central Anatolian region of Turkey in which more oriental life standards are more dominant while the other 5 students were selected by getting their consent from a state university located in Istanbul in Marmara region which is closer to western values so that a meaningful comparison could be made between these two different research contexts. All the participants of this study were chosen from the students enrolled in School of Foreign Languages in the universities that they were attending at the time of the study which was designed to determine the sociocultural factors on foreign language learning. Thus, these students were taught Academic English which they would need in their departments where they would get English-medium-instruction. This is the table that shows the profiles of the participants.

Table 1. Demographic information of participants

\begin{tabular}{|c|c|c|c|c|c|c|c|}
\hline Codes & Accommodation & Department & Age & Socioeconomic status & Hometown & $\begin{array}{l}\text { Prep year in } \\
\text { High School }\end{array}$ & $\begin{array}{c}\text { High School } \\
\text { Graduation }\end{array}$ \\
\hline I1 & Dormitory & International Relations & 19 & Above average & Edirne & Yes & $\begin{array}{l}\text { Social Science High } \\
\text { School }\end{array}$ \\
\hline I2 & Dormitory & Theology & 18 & Above average & Izmit & No & $\begin{array}{c}\text { Anatolian Religious } \\
\text { High School }\end{array}$ \\
\hline I3 & Family home & International Relations & 18 & Above average & İstanbul & No & High School \\
\hline I4 & Own home & Business Administration & 18 & Above average & İzmit & No & $\begin{array}{l}\text { Anatolian High } \\
\text { School }\end{array}$ \\
\hline I5 & Family home & Environmental Engineer & 19 & Above average & İstanbul & No & $\begin{array}{l}\text { Anatolian High } \\
\text { School }\end{array}$ \\
\hline ES1 & Own home & Industrial Engineer & 19 & Average & Tekirdağ & Yes & High School \\
\hline ES2 & Dormitory & $\begin{array}{l}\text { Metallurgy Science } \\
\text { Engineering }\end{array}$ & 19 & Below average & İzmit & No & $\begin{array}{l}\text { Anatolian High } \\
\text { School }\end{array}$ \\
\hline ES3 & Dormitory & Architecture & 19 & Below average & Kastamonu & No & Science High School \\
\hline ES4 & Own home & $\begin{array}{c}\text { Business Administration } \\
\text { Engineering }\end{array}$ & 18 & Above average & İzmit & No & $\begin{array}{l}\text { Anatolian High } \\
\text { School }\end{array}$ \\
\hline ES5 & Dormitory & Computer Engineering & 22 & Average & Ankara & No & $\begin{array}{c}\text { Anatolian } \\
\text { Vocational High } \\
\text { School }\end{array}$ \\
\hline
\end{tabular}

From Table 1, it can be understood that the student participants attending the state university in Istanbul were coded as I1, I2, I3, I4, and I5 whereas the ones enrolled in the state university in Eskisehir were coded as ES1, ES2, ES3, ES4, and ES5 so that their identities were shown to be "anonymous" as stated in the interviews. During the interviews, students were asked whether they had been familiar with their learning context before they started their higher education in the cities where they went for their study. All of the students in Istanbul had been there while the ones in Eskisehir went this city for the first time for their studies as they did not know much about the city of their university expect from ES1 who visited Eskisehir during a school trip. Thus, the familiarity level of the students with the learning context in
Istanbul was much higher than the ones in Eskisehir.

Another striking point in Table 1 is the socioeconomic status of the students in two different cities. The students in Istanbul categorized themselves as above average considering the economic conditions of Turkey while the ones in Eskisehir thought themselves either average or below average except from ES4 who considered his socioeconomic status as above average of the Turkish standards. The ones who claimed that they were above average stated that they could afford to buy what they wanted so they put themselves in that category.

Whether these learners had a prep year experience before they came to university was also equally important as their familiarity with an 
intensive language learning program would have a positive influence on their success. However, only I1 and ES1 had a prep year experience in their high schools though they both stated that it was not as efficient as the one they had in university.

\section{Data Collection Tool}

Interviews: All the data for this study were collected via the interviews. The interviews were held with 10 different students in two different universities in two different cities. Five students attending the School of Foreign Languages in one of the state universities in Istanbul were interviewed in Istanbul while the ones in the state university in Eskisehir were interviewed by using technology with video-conferencing. All the interviews were audio recorded by the researcher with the permission of the participants so that they could be transcribed for the later analysis. The duration of the interviews depended on the interviewee whose precious opinions were valued to a great extent. However, each interview took around 30 minutes. The interviews were conducted in the native tongue of the students which is Turkish so as to make them feel comfortable to share their own ideas freely and to prevent any misunderstanding. What is more, some concepts and terms related to different "categories of culture", "sociocultural learning" as well as "socioeconomic status" were explained in detail to the students to clarify what they had already known about these and to make them give proper responses to the questions including these terms.

The interview questions were written by the researcher considering the research questions. What is more, the researcher got an expert view before the use of the questions in the interviews from another academic. Thus, he made some minor changes in the interview questions taking the expert views of the colleague who wanted to contribute to both the reliability and validity of the study. Wasser and Bresler (1996) define this as "a process when the researchers bring together their different kinds of knowledge, experience, and beliefs to forge new meanings throughout the inquiry in which they are engaged" (p.13). The interview questions were semi-structured as participants were encouraged to exemplify what they had stated. What is more, Gall et al. (2003) think that "in qualitative research, the interview format is not tightly structured because the researcher's target is to make respondents feel free to express their view of a phenomenon in their own terms" (p.239).

\section{Data Analysis}

Case study tactics were used as for the analysis of this case study research and validation measures (Yin, 2014). Thus, procedures and questions were related to citations and research questions. Also, the validity of the interview questions was sustained by getting an expert view for the content appropriacy. Before the interviews were initiated, the interview questions were piloted with a student who was not included in this study. With these steps, face validity and reliability were both established.

As this is a case study, "analysis here is almost inevitably interpretive" (Cohen et al, 2007, p.469). Thus, all the qualitative data collected for the purpose of this study via interviews were analyzed "in order to find constructs, themes, and patterns that can be used to describe and explain the phenomenon being studied" (Gall et al., 2003, p.453). The transcriptions of the interviews were put into themes and categories (Krippendorp, 2004). From these categories which are defined as "the main groupings of constructs or key features of the text, showing links between units of analysis" (Cohen et al., 2007, p.478); certain codes, which define "the smallest element of material that can be analyzed" (Cohen et al., 2007, p.477), were all related to the research questions.

With the "codes" available and thematically categorized under the related research question, the data were ready for analysis. Some of the quotes from the transcriptions of the interviews were also given in the results section as Gall et al. (2003) claim that "direct quotes of the remarks by the case study participants were particularly effective because they clarify the emic perspective, that is, the meaning of the phenomenon from the 
point of view of the participants" (p.469). These quotes of the participant students clarified the case.

\section{Results}

\section{Cultural Elements in Language Teaching}

The participants were asked in the interviews whether culture teaching was given some kind of importance in the curriculums of their schools. All of the participants in the university in Istanbul said that culture was integrated with the curriculum whereas only ES2, ES3, and ES5 stated that culture was given some importance in their curriculums. However, ES1 and ES4 said that no importance was given. ES1 elaborated on the issue by saying:
"Instructors are more concentrated on teaching the contents of the book. Only very few of them share their own experiences with us but, in general, culture is not given sufficient importance in our education".

Though the participants in the university in Istanbul seemed to be quite satisfied with the cultural education that they got, there were some hesitations about the sufficiency of it among the learners in Eskişehir.

After sharing their thoughts about culture teaching, participants were asked about the categories of culture made by Adaskou et al. (1990) and whether these categories were covered in their classes. Here is the table that shows their responses.

Table 2. The cover of the components of culture in language classes (Adaskou et al., 1990)

\begin{tabular}{|c|c|c|c|c|c|c|c|c|c|c|}
\hline & I1 & I2 & I3 & I4 & I5 & ES1 & ES2 & ES3 & ES4 & ES5 \\
\hline $\begin{array}{l}\text { the aesthetic sense (media, cinema, } \\
\text { music and literature) }\end{array}$ & Yes & Yes & Yes & Yes & Yes & No & No & Partial yes & No & No \\
\hline $\begin{array}{l}\text { the sociological sense (family, } \\
\text { education, interpersonal relations, } \\
\text { material conditions work and } \\
\text { leisure, traditions) }\end{array}$ & Yes & Yes & Yes & Yes & Yes & Yes & Partial yes & Yes & Yes & Partial yes \\
\hline $\begin{array}{l}\text { the semantic sense (conceptions } \\
\text { and thought processes) }\end{array}$ & No & No & No & No & No & No & No & No & No & No \\
\hline $\begin{array}{l}\text { the pragmatic (or sociolinguistic) } \\
\text { sense ('appropriacy' in language } \\
\text { use) }\end{array}$ & Yes & Yes & Yes & Yes & Yes & Yes & Yes & Yes & Yes & Yes \\
\hline
\end{tabular}

It can be understood from Table 2 that in both universities, the pragmatic sense was given much more importance while teaching English as there was a consensus among the students that this was significantly emphasized in the lessons. ES1 explained:

"This is given so much importance as our instructors show the use of different words and sentence structures in different contexts and they always warn us to choose the appropriate word for a certain context. For instance, in a formal mail, there are some words that we have to avoid using".

This category (the pragmatic sense) was also emphasized by all the students in the university in Istanbul in the interviews. What is more, there was also a consensus among two students' groups in terms of the lack of the semantic sense in the lessons. However, when it comes to sociological sense, though students in Istanbul said that it was covered in the lessons, the ones in Eskisehir hesitantly said "yes". ES2 said:

"They are covered only when these topics are included in the book that we use as our main course book. Otherwise, they are not elaborated on much, unfortunately".

The biggest difference between these two student groups was the integration of the aesthetic sense of culture with the language lessons as the participants in Istanbul said that it was covered whilst the ones in Eskisehir said it was not covered at all expect from ES3 who said it was partially covered. I4 explained the situation:

"We have been exposed to foreign music and we try to understand the song both linguistically and culturally so I feel that I have developed myself in this musical sense a lot with the help of our lessons".

I1, I2, I3 and I5 agreed with their friend and said much interest was given specifically in music with respect to the aesthetic sense of culture. 
Another categorization of culture was made by Byrd et al. (2011) and students were also asked whether these categories were covered in their lessons. Here is the table that shows their responses.

Table 3. The cover of the components of culture in language classes (Byrd et al., 2011)

\begin{tabular}{|c|c|c|c|c|c|c|c|c|c|c|}
\hline II & 1 & I2 & I3 & I4 & I5 & ES1 & ES2 & ES3 & ES4 & ES5 \\
\hline $\begin{array}{l}\text { Cultural Products (tangible products- } \\
\text { literature, art, crafts and song, dance) }\end{array}$ & Yes & Yes & Yes & Yes & Yes & Yes & Yes & Yes & Yes & No \\
\hline $\begin{array}{l}\text { Cultural Practices (knowledge of what to do, } \\
\text { when, and where) }\end{array}$ & Yes & Yes & Yes & Yes & Yes & No & No & Yes & No & No \\
\hline Cultural Perspectives (ideas and a & No & No & No & No & No & No & No & No & No & No \\
\hline
\end{tabular}

It can be concluded from Table 2 that all the participants reached a consensus both on the cover of cultural products expect from ES5 and on the lack of cultural perspectives in their language lessons. However, as for cultural practices, all the participant students in İstanbul agreed that they covered it whereas the ones in Eskisehir said that they did not cover anything about it except from ES3.

\section{Elements of sociocultural learning}

During the interviews, students were asked about where they stayed, their socioeconomic status and the city of their university. They were later asked to relate them to the way they studied English language and how these variables affected their sociocultural learning. It was found from their responses that the accommodation type, socioeconomic status and the city of their university played a crucial role in both their cultural and sociocultural learning.

I1, I2, ES2, ES3, and ES5 stated that they stayed in the dorm. I1 and I2 talked about the positive sides of the dormitory life on their studies whereas ES2, ES3 and ES5 mentioned the negative sides of their dormitory lives. I1 said:

"I had some very determined friends in my dorm so they were encouraging me to study for my lessons. I sometimes consulted my friends for the points that were confusing me and they explained them to me".

I2 talked about another strength of her dorm life by saying:
"Our dorm was organizing some extra-curricular activities such as seminars or handcraft workshops in which I had participated. What is more, there was a foreigner next door so I was practicing my language skills with her. There were some times when I also asked other people to explain some of the points that I had not understood in the lessons".

This quote obviously showed positive influence of dormitory life both on the cultural and sociocultural learning. However, the ones in Eskisehir talked about the negative sides of dormitory life. ES5 said:

"The dorm was so crowded and noisy. Also, people did not respect each other and they were behaving themselves without paying any attention to the rules and regulations."

When it comes to the people living in their own homes alone, I4, ES1, and ES4 all said it was something negative for their learning. ES4 explained:

"As I was all alone at home, there was no one to motivate me and encourage me to study for my lessons. If I had had a friend who was inspiring, I would have studied more English. However, what I did was to find some activities that would engage me such as watching films, which distracted my concertation on my studies".

I3 and I5 said that they stayed in their family home which might be considered as both advantageous due to the lack of household responsibilities and disadvantageous because of the interruptions from the family members while studying. 
Another factor participant students stated as one of the most significant factors that affected their sociocultural learning was the socioeconomic status which they all thought that there was a direct link between these two. I5 elaborated on the issue:

"If your socioeconomic status is high enough to give you the freedom to do what you want, this will pave you the way to develop your sociocultural knowledge because unless you have money, you will not be able to afford to visit museums, watch theaters and movies. What is more, you cannot go abroad to broaden your horizon. Even in a simplest basis, you cannot socialize with your friends even in a café where you must pay to eat and drink."

It can also be understood from Table 1 that all the participant students in İstanbul categorized their socioeconomic status as "above the average" considering the conditions of the country while the ones in Eskişehir thought themselves either as average or below average apart from ES4 who said his condition was above average.

Students were also asked about the relation and the effect of the city where they study on their sociocultural and cultural learning. The participants in İstanbul all said that the city had some positive influence both on their cultural and sociocultural learning. I5 explained this situation:

"Istanbul is a culturally rich city as it used to the capital of several civilizations and empires so it attracts a lot of tourists from all around the country. Therefore, you can meet with people from different culture and learn from them. This makes me develop myself linguistically as we can speak English with them. In addition to linguistic development, people can broaden their horizons in this city as they learn from each other".
From this perspective, it can be understood that the learners in İstanbul thought that the city contributed a lot to their language and cultural development as well as sociocultural learning as there are so many different profiles of people coming from different places and cultures. When it comes to the students in Eskisehir, they could not relate the city to their cultural and linguistic development but the university context which contributed a lot to their sociocultural and linguistic development. ES2 elaborated on the issue:

"I do not think the city has come cultural roots but our university has some international students with whom you can speak and share your cultural knowledge and experiences. This contributes a lot to your linguistic competence. What is more, there are some cultural activities such as cinemas and theatres in the city so that you can enjoy and spend your free time with your friends".

This quote also shows that participants in Eskisehir related their sociocultural and cultural improvement to the facilities that their university offered to them. Though Eskisehir also offers some cultural activities, it is not as culturally rich as Istanbul in terms of history and different profiles of people.

\section{The Way the Elements of Sociocultural Learning Handled in Two Different Contexts}

In the interviews, students were informed about the certain elements of sociocultural learning and they were asked whether they experienced them in their language learning process. Here is the table that shows their responses.

Table 4. The existence of elements in sociocultural learning of the language learners

\begin{tabular}{|c|c|c|c|c|c|c|c|c|c|c|}
\hline & I1 & I2 & I3 & I4 & I5 & ES1 & ES2 & ES3 & ES4 & ES5 \\
\hline Bilingual instruction & Yes & Yes & Yes & Yes & Yes & Yes & Yes & Yes & Yes & Yes \\
\hline Pragmatics of the language & Yes & Yes & Yes & Yes & Yes & Yes & Yes & Yes & Yes & Yes \\
\hline Instruction based on learners' interest & No & No & No & No & No & No & No & No & No & No \\
\hline The guidance of the teachers & Yes & Yes & Yes & Yes & Yes & Yes & Yes & Yes & Yes & Yes \\
\hline Scaffolding & Yes & Yes & Yes & Yes & Yes & Yes & No & Yes & No & Yes \\
\hline
\end{tabular}

When participant students were asked whether their teachers turned to their native tongue (Turkish) in the lessons, all of them said that they did because they had to explain some of the points, especially grammar, which we may find difficult to understand.

All of the participants also stated that their instructors showed them the pragmatics of the language. They were informed about the 
importance of context in terms of the word choice and grammatical structures.

When it comes to the instruction based on learners' interest, all of the participants said this was not the thing that they had faced in the classroom. ES4 explained:

"This was unfortunately not the case. Whatever existed in the book or in the materials was covered in the lessons. However, we did not find them interesting at all. Students must be motivated and we can be more enthusiastic in the lessons only when our interests are paid attention to".

Participants were complaining about the lack of instruction based on their interest. However, they all said that they were satisfied with the guidance from their instructors as they directed them to on- task behaviors both in the class and out of the class with the assignments given to them.

Students were also asked whether they got any help about something they did not understand from a person who was considered to be in a better level in terms of language proficiency (scaffolding). All of the participants in Istanbul said "yes" whereas only ES1, ES3, and ES5 admitting getting help from their peers as ES2 and ES4 said they did not consult to anyone for help. Students were also asked to whom they consulted to get help and which skill was their main concern to get help. They were also asked whether it was beneficial. Here is the table that shows it.

Table 5. Scaffolding of the learners

\begin{tabular}{|c|c|c|c|c|c|c|c|c|c|c|}
\hline & I1 & I2 & I3 & I4 & I5 & ES1 & ES2 & ES3 & ES4 & ES5 \\
\hline Who? & Instructor & Classmate & Classmate & Classmate & Classmate & Classmate & - & Classmate & - & Classmate \\
\hline Which skill? & $\begin{array}{l}\text { Writing/ } \\
\text { Grammar }\end{array}$ & $\begin{array}{l}\text { Writing/ } \\
\text { Grammar }\end{array}$ & Writing & Writing & $\begin{array}{l}\text { Writing/ } \\
\text { Grammar }\end{array}$ & $\begin{array}{l}\text { Grammar/ } \\
\text { writing }\end{array}$ & - & Grammar & - & Grammar \\
\hline Benefit? & Yes & Yes & Yes & Yes & yes & & - & Yes & - & Yes \\
\hline
\end{tabular}

From the table, it can be understood that participant students mostly preferred to get help from their friends except from I1 who got help from the instructor saying that she was by far the best student in the class so there was no one to reach her level. What is more, all the participants in Istanbul said they needed help to improve their writing along with grammar which was mentioned by I1, I2, and I5 whereas the ones in Eskisehir said that they needed help in terms of grammar. Only ES1 stated that he got help to improve his writing as well as his grammar. All the participants who got help said that it was a beneficial process expect from ES2 and ES4, both of whom did not have any scaffolding.

When participant students were asked about each of these sociocultural learning elements and how they were handled in the classroom, they were asked whether they could relate these learning processes to the city in which they were studying English. All of the participants in Istanbul said that they could relate all these elements of sociocultural learning to city of their university. I1 explained the situation:

"There is so much of influence of Istanbul on our sociocultural learning as this is a well-developed city in every sector so education is one of them. The availability of the quality instructors and education is because of the fact that one can easily reach these sources in Istanbul".

This quote shows that Istanbul has an influence on the sociocultural learning of the language learners here. However, when the same question was asked to the students in Eskisehir, they all said that they could not relate the city to these sociocultural learning elements mentioned in the interviews. Only ES3 and ES5 said that they could be related to the university but not the city. ES3 explained that:

"There is no connection between these sociocultural learning elements and the city but I can relate them to the university where we get our education because I think the quality of education is above the average considering the condition of Turkey as we have very qualified teachers here".

It can be concluded that learners in Eskisehir did not find any relation between the atmosphere of the city and their sociocultural learning facilities.

\section{Discussion and Conclusion}

It can be understood that culture teaching must be given more importance in language classes as 
language and culture are interrelated components, which cannot be considered separately (Sun, 2015). It was found that students in Eskisehir said it was not given sufficient attention to it. However, it was found in the study conducted by Aidinlou and Kejal (2012) that teaching cultural elements of the language helped the participant students gain the better insight of the English language as a foreign language and there was $24 \%$ increase in their performance while they were doing culture dependent tasks.

Another important point to notice is that the "pragmatic sense" of culture was more focused during the lessons. This was understandable as it was easy to teach with the certain grammatical explanations with the right word choices in certain contexts as "L2 pedagogy encompasses any form of educational activity designed to promote the internalization of, and control over, the language that learners are studying" (van Compernolle \& Williams, 2013, p.278). What is more, "sociocultural sense" of culture was said to be taught in two different contexts while the "aesthetic sense" was ignored in Eskisehir. This might be related to the context of the learning/teaching environment as it highly affects the language teaching procedure (Pazyura, 2016). "Semantic sense" of culture and "cultural perspectives" were both ignored in classes because these elements of culture might be considered as "abstract" by the teachers so it was difficult to teach whereas the "pragmatic sense" of culture and "cultural practices" might be thought to be more "concrete"; thus, it was easy for the teachers to integrate them with their lesson plans.

Accommodation type of the students also is another factor that affects their sociocultural learning as the ones staying in dorms in Istanbul talked about the positive sides of their stay as they cooperated with their peers in terms of their language learning. This cooperation and collaboration spirit positively affect their language learning process as Lee (2015) mentions the importance of this in her experiences in teaching English at Christopher House in Chicago where students from low-income families (mostly immigrants) help each other a lot.

Socioeconomic status of the learners is another equally important factor that affects their sociocultural learning. It was found in the study of Bonilla and Cruz-Arcila (2014) that the socioeconomic status of the learners negatively affects their sociocultural learning and put the ones living in the suburban parts of the cities in Colombia in a disadvantageous position in terms of economic, technologic and sociocultural factors. Thus, the facilities that the city offers have an influence on the language learning process of the learners. In this study, it was found that the university in Eskisehir created some opportunities for the learners to benefit from them despite the lack of variety of the activities in Eskisehir which cannot be compared to Istanbul in this sense.

It was found in this study that there was no instruction based on the learners' interest and all of the participant students complained that the instructors were in a rush to cover the contents of the books. This might be due to the pacing and the syllabus that teachers had to keep up with. However, it was the teachers' role to guide and create an environment that will motivate the students to learn according to the sociocultural learning theories (Eun \& Lim, 2009). Therefore, the integration of certain contents with the curriculum in accordance with the interests of the learners will positively affect the process. In the study carried out by Ivygina et al. (2019), it was shown that the addition of historical texts motivated the Turkmen students learning Russian as a foreign language and the level of their sociocultural competence increased a lot as well as their creativity, desire to acknowledge other cultures, and their academic skills in general. What is more, students' desire to cooperate with the teachers increased, as well.

When it comes to the scaffolding of the students, most of them stated the benefit of this process as Cullen et al. (2013) stated the importance of the creation of supportive learning environments and learning communities characterized by high levels of social presence which result from strong collaboration, interactivity, mutual respect and interdependence among the students. In order to increase the efficiency of this process, learners with similar interest might be encouraged to study together ( $\mathrm{Li}$ 2011; Rideout et al. 2008; Yeh 2010) because this will enable further opportunities to enhance belongingness; collaboration in small groups 
(Dickey 2004; Ducan and Barnett 2009; Li 2011). However, it is interesting that participants in this study pointed out that they were scaffolding just to improve their writing and grammar skills. However, scaffolding among the learners will also help them develop their speaking skills as it was shown because cooperation among learners will contribute a lot to their speaking performance (Darmuki et al., 2018; Usman et al., 2018).

\section{References}

Adaskou, K., Britten, D., \& Fahsi, B. (1990). Design decisions on cultural content of a secondary course for Morocco. ELT Journal, 44(1), 3-10.

Aidinlou, N. A., \& Kejal, D. A. (2012). Socio-cultural factors and teaching a foreign language. International Journal of Social Science and Education, 2(2), 139-143.

Atkinson, D. (1987). The mother tongue in the classroom. ELT Journal, 41(4), 241-247.

Bates, D. G., \& Plog, F. (1991). Human adaptive strategies. New York: McGraw-Hill.

Bonilla, S. X., \& Cruz-Arcila, F. (2014). Sociocultural factors involved in the teaching of English as foreign language in rural areas of Colombia: an analysis of the impact on teachers' professional development. Profile: Issues in Teachers' Professional Development, 3(2), 28-33.

Brown, H. D. (2007). Principles of language learning and teaching. (5th Edition). New York: Pearson.

Byram, M. (1997). The intercultural dimension in "language learning for European citizenship." In M. Byram \& G. Zarate (Eds.), The sociocultural and intercultural dimension of language learning and teaching (p.17-20). Strasbourg, France: Council of Europe Publishing.

Byrd, D. R., Hlas, A. C., Watzke, J., \& Valencia, M. F. M. (2011). An examination of culture knowledge: A Study of L2 teachers' and teacher educators' beliefs and practices. Foreign Language Annals, 49(1), 4-39.

Canale, M., \& Swain, M. (1980). Theoretical bases of communicative approaches to second language teaching and testing. Applied Linguistics, 1(1), 1-47.

Cohen, L., Manion, L. \& Morrison, K. (2007). Research Methods in Education (6th edition). London: Routledge.
Cook, V. (2008). Second language learning and language teaching (4th, ed.). London: Hodder Education.

Cullen, R., Kullman, J., \& Wild, C. (2013). Online collaborative learning on an ESL teacher education programme. ELT Journal, 67(4), 425-434.

Darmuki, A., Andayani, Nurkamto, J., \& Saddhono, K. (2018). The development and evaluation of speaking learning model by cooperative approach. International Journal of Instruction, 11(2), 115-128.

Dickey, M. D. (2004). The impact of Web-logs (Blogs) on student perceptions of isolation and alienation in a web-based distance-learning environment. Open Learning, 19(3), 279-291.

Ducan, H. E., \& Barnett, J. (2009). Learning to teach online: What works for pre-service teachers. Journal of Educational Computing Research, 40(3), 357-376.

Edstrom, A. (2006). L1 use in the L2 classroom: One teacher's self-evaluation. The Canadian Modern Language Review, 63(2), 275-292.

Eun, B., \& Lim, H-S. (2009). A sociocultural view of language learning: The importance of meaning-based instruction. TESL Canada Journal, 27(1), 13-26.

Fahim, M., \& Haghani, M. (2012). Social perspectives on foreign language learning. Journal of Language Teaching and Research, 3(4), 693-699.

Gall, M. D., Gall, J. P., \& Borg, W. R. (2003). Educational research. Boston: Pearson.

Genesee, F. (1994). Integrating language and content: Lessons from immersion. Educational Practice Report 11. National Center for Research on Cultural Diversity and Second Language Learning.

Hitchcock, G., \& Hughes, D. (1995). Research and the Teacher (second edition). London: Routledge.

Kaufman, D. (2004). Constructivist issues in language learning and teaching. Annual Review of Applied Linguistics, 24, 303-319.

Kim Anh, K. H. (2010). Use of Vietnamese in English language teaching in Vietnam: Attitudes of Vietnamese university teachers. EFL Journal, 3(2), 119-128.

Kramsch, C. (1998). Language and culture. Oxford: Oxford University Press.

Krippendorp, K. (2004). Content analysis: An introduction to its methodology. Thousand Oaks, CA: Sage. 
Lantolf, J. P., \& S.L. Thorne. (2006). Sociocultural theory and the genesis of second language development. Oxford: OUP.

Lee, M. S. (2015). Implementing the sociocultural theory while teaching ESL. Student Perspectives About Civic Engagement, 1(1), 2835.

Li, Z. (2011). Learners' reflexivity and the development of an e-learning community among students in China. Research in Learning Technology, 19(1), 5-17.

McLaughlin, M.W. (1994). Strategic sites for teachers' professional development. In P.P. Grimmett \& J. Neufeld (Eds.), Teacher development and the struggle for authenticity: Professional growth and restructuring in the context of change (p.3151). New York: Teachers College Press.

Nault, D. (2006). Going global: Rethinking culture teaching in ELT contexts. Language, Culture and Curriculum, 19(3), 314-328.

Nunan, D. (1992). Sociocultural aspects of second language acquisition. Cross Currents, 19(1), 16-24.

Özfidan, B., Machtmes, K. L., \& Demir, H. (2014). Sociocultural factors in second language learning: A case study of adventurous adult language learners. European Journal of Educational Research, 3(4), 185-191.

Pazyura, N. (2016). Influence of sociocultural context on language learning in foreign countries. Comparative Professional Pedagogy, 6(2), 14-19. doi:10.1515/rpp-2016-0012.

Rideout, G., Bruinsma, R., Hull, J., Modayil, J. \& Modayil, J. (2008). Online learning management systems (LMS) and sense of community: A pre-service practicum perspective. Canadian Journal of Learning and Technology / La revue canadienne de l'apprentissage et de la technologie, 33(3), Canadian Network for Innovation in Education. Retrieved December 1, 2020 from https://www.learntechlib.org/p/42932/.

Spivey, N. (1997). The constructivist metaphor: Reading, writing, and the making of meaning. San Diego: Academic Press.
Schweers, W. Jr. (1999). Using L1 in the L2 classroom. English teaching forum, 37(2), 6-7.

Sun, Ch. (2015). The cultivation of cross-cultural communication competence in oral English teaching practice. English Language Teaching, 8(12), 7-9. doi: 10.5539/elt.v8n12p7.

Usman, B., Champion, I., Muslem, A., \& Samad, I. A. (2018). Progressive peer evaluation: Important but absent in EFL speaking classes. Studies in English Language and Education, 5(2), 308-327.

van Compernolle, R. A., \& Williams, L. (2013). Sociocultural theory and second language pedagogy. Language Teaching Research, 17(3), 277-281. https://doi.org/10.1177/1362168813482933

Vygotsky, L. (1978). Mind in society: The development of higher psychological processes. Cambridge, MA: Harvard University Press.

Vygotsky, L.S. (1987). Thinking and speech. In R. Rieber \& A. Carton (Eds.), The collected works of L.S. Vygotsky (N. Minick, Trans.) (vol. 1, p.39-285). New York: Plenum Press.

Vygotsky, L.S. (1997). Educational psychology. Boca Raton, FL: St. Lucie Press.

Wasser, J. D. \& Bresler, L. (1996). Working in the interpretive zone: Conceptualized Collaboration in qualitative research teams. Educational Researcher, 25(5), 5-15.

Wright, M. (1996). The cultural aims of modern language teaching: Why are they not being met? Language Learning Journal, 13, 36-37.

Yeh, Y. (2010). Integrating collaborative PBL with blended learning to explore preservice teachers' development of online learning communities. Teaching and Teacher Education, 26, 1630-1640.

Yin, R. K. (2014). Case study research: Design and methods (5 $5^{\text {th }}$ ed). Los Angeles: Sage. 